\title{
Tourism demand and migration nexus in Small Island Developing States (SIDS): applying the tourism demand model in the Pacific region
}

\author{
Kantaro Takahashi \\ Shumei University, Japan \\ takahashikantaro1988@gmail.com
}

\begin{abstract}
This paper demonstrates the nexus of tourism demand and the migrants from small island developing states (SIDS) in the Pacific region using an econometric approach. Emigrants are an important element of island society. The tourism industry is crucial for many islands. Although the nexus of tourism and migration has been discussed in developed countries, especially in terms of Visiting Friend and Relatives tourism, this topic is more significant for (SIDS). A tourism demand model considers the regional differences of ten island states. The result shows that migrants generate tourism demand. This result, therefore, indicates that migrants should be considered one of the possibilities for generating tourism demand.
\end{abstract}

Keywords: islands, migration, multi-level model (generalized mixed model), Pacific region, Small Island Developing States (SIDS), tourism demand

https://doi.org/10.24043/isj.84

(C) 2019-Institute of Island Studies, University of Prince Edward Island, Canada.

\section{Introduction}

According to William and Hall (2000), some causal relationships exist in the tourism and migration nexus. One such cause is that tourism generates labor migration to fulfill the employment needs of the tourism industries, which depend on particular skills from foreign countries. The other cause is that migration leads to tourism demand because of friendship and kinship networks. In this case, migrants become tourists when returning to visit friends and relatives in their areas of origin: this is known as Visiting Friends and Relatives (VFR) tourism demand.

This paper aims to demonstrate the tourism and migration nexus in the Pacific Islands. Categorized as MIRAB (Migration, Remittance, Aids and Bureaucracy) States by Bertram and Watters (1985), many Small Island Developing States (SIDS), particularly in the Pacific region, are influenced by foreign developed countries, and emigrants are significant for these islands' societies. According to previous work, many of the emigrants from the Pacific islands maintain relationships with their relatives and local communities (Browne \& Mineshima, 2007). From this situation, migrants might visit their home countries to meet with their family or friends, influencing tourism demand. This paper applies a tourism demand model to selected states to compare the impact of migration relative to other demand variables, such as income and relative prices.

This viewpoint could be significant for economic policymaking in the Pacific islands because their economic structures tend to have strong relationships to immigrant communities in foreign countries. Moreover, the tourism industry is significant for economic development in these islands since tourism is one of the main industries. Therefore, understanding tourism demand is crucial for Pacific island economies. 


\section{Literature review}

The relationship between tourism and migration is a significant theme in tourism studies. For example, in diaspora tourism, migrants and their descendants return to ancestral homelands in search of their roots and personal heritage. Huang et al. (2013) find an association among immigrants to the USA between the number of diaspora tourism trips and feeling at home in one's parents' country of origin. In addition, those who have experienced extended stays are more likely to feel at home in their ancestral homeland, and both length and frequency of diaspora tourism trips are found to be associated with immigrants' connection to the land of their ancestors. Meanwhile, linkage of migration stock and tourism demand is considered especially pertinent in the field of tourism economics. According to Deyer et al. (2010), choice of destination is influenced by ethnic and migration factors, which generate tourism demand. This traveling style is considered a form of 'visiting friends and relatives' (VFR) tourism.

Several empirical studies measure the volume of migration and tourism demand in developed countries. Comparing VFR tourism and other forms of tourism demand in Australia, Dwyer et al. (2014) find a strong linkage between tourism demand and migration. Etzo et al. (2014) discuss the nexus of Italian outbound tourism and migration, disaggregated by purpose of visit. This study focuses on the stock of Italian emigrants and finds a significant effect on Italian outbound tourism, while foreigners residing in Italy are significant for both VFR tourism and non-VFR tourism (business and holiday visits). These studies mainly discuss the relationships between migration and tourism flows since both Australia and Italy have a long history of migration, though their patterns of migration differ from one another: Australia is basically an immigration country, while Italy is an emigration country. Tourism demand and migrant stocks are likely to be related in both countries.

SIDS in the Pacific also have a long history of emigrants. As a result, migrants are a vital factor for island societies and economies (Christensen \& Mertz, 2010). Some islands have low wages and limited employment opportunities. Due to this socio-economic background, some people, especially in the younger generations, leave the islands to work in other countries. Some of them remit money back to their home islands. These remittances are an influential revenue source for these island economies. According to previous work, the MIRAB concept mainly comes from the social situation of the Pacific islands, and it illustrates the characteristics of certain kinds of island economies (Bertram \& Waters, 1985). Guan and McEloy (2012) divide SIDS into immigrant and emigrant islands and analyze the determinants of migration for each group. They find that immigrant islands tend to have positive economic characteristics such as high per capita income levels and tight labor markets. In addition, they have significant international trade, investment, and tourism linkages. Migrants affect their island economies, particularly in terms of international trade.

Because many small islands suffer from a number of geographical disadvantages, such as small land area, remoteness, and vulnerable nature resources, these islands' socioeconomic are highly dependent on outside states. SIDS are categorized as vulnerable regions by the UN (UN-OHRLLS, 2016). Briguglio (1995) points out the economic vulnerabilities of small states and argues that small states have scarce natural resources and low inter-industry linkage; thus, most of their products depend on the import-oriented economy. Furthermore, the manufacturing trade is disadvantaged for small states because of higher cost per unit in the manufacturing sector (Briguglio, 1998). Thus, they need to expand their export markets so that they can pay for their imports without having a large manufacturing sector.

Previous research into small states (usually islands) has shown the interrelatedness of geographical and economic factors (Armstrong \& Read, 2002, 2003, 2006). In these studies, tourism is often considered to be a key industry contributing to the small state economies. Pratt (2015) estimates the economic impact from tourism expenditures for some SIDS using CGE models and finds that the transportation sector remains as a key sector and that income 
revenue is small, even though tourism generates a large amount of economic activity. Also, from a Tourism Led Growth perspective, island economies experience economic growth through tourism development. Narayan et al. (2010) analyze the Pacific Island Countries of Fiji, Tonga, the Solomon Islands, and Papua New Guinea. They confirm the relationship between tourism development and economic growth using an econometric approach that applies an economic growth model. Moreover, Seetnanah (2011) reports the economic impact of tourism on 19 islands. The study confirms interactions between tourism revenue and economic development. In addition, Liu et al. (2018) apply a Bayesian model to estimate the tourism impact for economic growth in Mauritius and find that tourism could lead to economic growth. The export revenue from international tourism demand is thus important for many small island economies.

In terms of migration and international trade linkages, Egger et al. (2011) suggest that migration may influence international trade between origin and destination countries. As major contributor to the international trade of goods and services, tourism is related to migrants living in foreign countries. Fourie and Santana-Gallego (2013) analyze the relationship of ethnic reunion and cultural affinities with tourism demand from a global perspective. They show that historical migration nexuses, such as cultural and ethnic similarity, are related to the international tourism market. Balli et al. (2016) explore the nexus of tourism and immigration, using data from 34 countries in the Organization for Economic Cooperation and Development (OECD) and 52 others middle- to low-income countries to shows that immigrants to OECD countries have a positive advertising effect for their countries of origin, inducing tourism flows from OECD countries. These studies all indicate that international tourism demand is related to migration stock. Although many small island states are also a source of large numbers of migrants in foreign countries, there is little empirical research demonstrating a relationship between tourism demand and migration stock.

This paper identifies the relationship between migrants and tourism demand for Pacific islands. As previous studies have noted, many migrants maintain relationships with their ancestral countries, for instance by sending remittances. Although remittances are a cash flow from a foreign country to an island, migrants who have family in other countries also influence the movement of people. VFR tourism is representative of this kind of tourism flow, and previous works focusing on developed countries have mentioned tourism and migration linkages. Migration is also a significant theme for SIDS, however, and the tourism demand nexus should be discussed in this context as well, particularly given that policymakers may need to consider migrants as a factor for tourism.

\section{Methodology}

This paper applies a tourism demand model to demonstrate the linkages between migration and tourism flows in the Pacific islands. Previous studies on tourism demand have mostly focused on developed countries. In the present paper, tourism demand is regarded as one of the services and commodities of international trade and is treated as a luxury service from an economic perspective (Eilat \& Einav, 2004; Zhang \& Jensen, 2007; Keum, 2010). Tourism demand models discuss the tourism determinants and forecast tourism demand (Song et al., 2012; Song \& Li, 2008). Most studies focus on demand in one destination. Some studies discuss the determinants of tourism demand using an econometric approach (Witt \& Witt, 1995; Garín-Mun, 2006; Khadaroo \& Seetanah, 2007; Santana-Jimenez \& Hernandez, 2011). From this perspective, the income of the countries of origin and the price difference between the origin and destination are considered general determinants. Most studies include these general variables to avoid omitted variable bias, then include other variables such as the migration effects. 
The present study applies the general variables, including the migration effect. Basically, the migration effect is represented by the migration stock, which is the number of migrants who live in countries outside of the island states. This variable indicates the push effect factor for tourists from foreign countries (Etzo et al., 2014). In Equation 1, the migration variable is added to the model:

$$
\begin{aligned}
& \log (T D)_{i j}=\log \left(\text { Migration }_{i},\right)+\left(G D P C A P_{i}\right)+\left(P O P_{i}\right)+\left(R P_{i j}\right)+\log \left(\text { Distance }_{i j},\right)+\text { Colony } \\
& \text { Language }+
\end{aligned}
$$

where " $i$ " and " $j$ " denote the origin and destination respectively; and "TD" represents tourism demand. In this paper, tourism demand is represented by international tourism arrivals since many previous papers also use tourism flow from origin " $i$ " to destination " $j$ " as the demand variable (Witt \& Witt, 1995). "Migration" shows the migration effect, as mention above. "GDPCAP" indicates the income effect on tourism demand from countries of origin. This variable shows income elasticity for tourism demand because tourism is regarded as a luxury good in international trade (Lim, 1997). To measure the income effect, this paper uses GDP per capita as a variable. " $R P$ " represents the price difference between origin and destination. This variable indicates the tourist preference for price difference. "Consumer Price Index" and "Exchange Rate" are utilized to create the indicator as shown below:

$$
R P_{i j}=\left(C P I_{j} / C P I_{i}\right) /\left(E X_{j} / E X_{i}\right)
$$

where "CPI" indicates the consumer index price. "EX" indicates the exchange rate (local currency unit per U.S. dollar). The assumption of this variable shows that Pacific SIDS have more significant variables because they attract much richer tourists than do other destinations. Price has a negative relationship with tourism demand (Dogru et al., 2017; Lim, 1997). "TRANSPORTATION COST" represents the transportation cost between the origin and the destination. Transport cost generally shows a negative relationship with tourism demand (Witt \& Witt, 1995). To capture the transportation effect, "Geographical Distance" is used as a variable in this paper because remoteness is one of the characteristics of SIDS.

In tourism demand models, qualitative variables are also often added. For example, colonial relationships and common language are often used to explain tourism demand (Fourie \& Santana-Gallego, 2011; Fourie \& Santana-Gallego, 2013; Vietze, 2012). These qualitative variables are important for Pacific islands since they have colonial histories.

\section{Data}

The data resources for the model are listed in Table 1. The tourism flow is from a dataset published by the UNWTO (2015). The explanatory variables (such as GDP per capita, population, consumer price index (CPI), and exchange rate) are from the World Development Indicators (World Bank, 2017). Meanwhile, distance variables, colony, and language relationship are taken from a CEPII dataset calculated by Mayer and Zignago (2011). The data resources on migrants are issued by the World Bank (2013). This data is created by applying weights based on population censuses of individual countries to the UN Population Division's estimates of total migrant stocks. The calculation method is based on Ratha and Shaw (2006). This variable indicates the approximated migration elasticity for tourism demand.

This paper sets the period in 2010. Migration data is not published in every year. The publication data can be obtained in the period of 2010, 2013, and 2018 according to the World Bank website. The World Bank sets the period year for other economic variables, such as CPI (described as price change in time series) to 2010. For these reasons, this paper carries out the cross-sectional analysis to estimate the regression model. 
Table 1: Data description.

\begin{tabular}{|c|c|c|}
\hline Variables & Definition & Resource \\
\hline $\mathrm{TD}_{\mathrm{ij}}$ & The number of tourists from origin "i" to destination "j" & Yearbook of Tourism Statistics (2015) \\
\hline Migration $_{\mathrm{i}}$ & Migration stock origin "i" in 2010 & Ratha \& Shaw (2006) \\
\hline GDPCAP $_{i}$ & $\begin{array}{l}\text { GDP per capita in origin " } \mathrm{i} \text { " in } 2010 \text { (constant } 2010 \\
\text { US\$) }\end{array}$ & $\begin{array}{l}\text { World Development Indicators } \\
\text { (2017) }\end{array}$ \\
\hline \multirow[t]{2}{*}{$\mathrm{POP}_{\mathrm{i}}$} & Population Size in origin "i" in 2010 & $\begin{array}{l}\text { World Development Indicators } \\
\text { (2017) }\end{array}$ \\
\hline & Relative price effect among two sites & \\
\hline \multirow[t]{2}{*}{$\mathrm{RP}_{\mathrm{ij}}$} & $\mathrm{RP}_{\mathrm{ij}}=\left(\mathrm{CPI}_{\mathrm{j}} / \mathrm{CPI}_{\mathrm{i}}\right) /\left(\mathrm{EX}_{\mathrm{j}} / \mathrm{EX}_{\mathrm{i}}\right)$ & $\begin{array}{l}\text { World Development Indicators } \\
\text { (2017) }\end{array}$ \\
\hline & $\begin{array}{l}\text { "i": Origin } \\
\text { "j": Destination } \\
\text { CPI: Consumer Price Index }(2010=100) \\
\text { EX: Exchange rate }(\text { LCU per US\$) }\end{array}$ & \\
\hline Distance $_{\mathrm{ij}}$ & Geo distance between origin "i" and destination "j" & Mayer \& Zignago (2011) \\
\hline Colony & $\begin{array}{l}\text { Dummy variable shown the colony relationship } \\
\text { between origin "i" and destination "j" }\left(Y e s=1, N_{0}=0\right)\end{array}$ & Mayer \& Zignago (2011) \\
\hline Language & $\begin{array}{l}\text { Dummy variable shown the relationship } \\
\text { whether same language between } \\
\text { origin "i" and destination "j" }\left(\mathrm{Yes}_{\mathrm{e}}=1, \mathrm{No}_{\mathrm{o}}=0\right)\end{array}$ & Mayer \& Zignago (2011) \\
\hline
\end{tabular}

Table 2 shows the list of origins and destinations. Ten islands are included. These countries are in the South Pacific region and can be classified as MIRAB States. These islands are considered to have similar socioeconomic situations. Therefore, the model considers all of the islands as the unit of analysis.

\section{The model}

Although this paper focuses on ten islands to estimate the statistical model, there is the risk of estimation bias on account of regional differences, such as the size of tourism demand. Equation 3 shows the simple linear model estimated by Ordinary Least Square:

$$
Y=\alpha+f(X \beta)+\varepsilon, \varepsilon \sim N\left(0, \sigma^{2}\right)
$$

" $X$ " shows the matrix of explanation variables in Equation 3. " $\beta$ " is the matrix for coefficients of the explanation variables. " $\alpha$ " shows the common intercept. " $\varepsilon$ " shows the error term with mean " 0 " and variance " $\sigma$ " for the model. In this model, intercept " $\alpha$ " and each of coefficients " $\beta$ " are considered fixed common effects. However, the size of tourism demand differs among the islands. A multi-level analysis is used to account for random effects and avoid bias due to the size of tourism demand:

$$
Y=\alpha+f(X \beta)+Z v+\varepsilon
$$

" $Z$ " shows the categorical variables which influences to response variables. In this paper, ten islands are considered as categorical variables. Categorical effects are also labeled as random effects. " $v$ " shows the coefficient of random effects considered as the heterogeneity of each 
island. In the estimation, these random effects are shown as the "variance of intercepts". This variance accompanies the mean " 0 " and variance " $\sigma^{2}$ " in each of group. This paper applies this estimation method for the dataset collected from the ten islands. In this method, maximum likelihood estimation is carried out.

Table 2: List of destinations and origins.

\begin{tabular}{|c|c|c|c|c|c|}
\hline Destination (j) & Origin (i) & & Destination (j) & Origin (i) & \\
\hline \multirow[t]{9}{*}{ Fiji } & India & Germany & $\begin{array}{l}\text { Papua New } \\
\text { Guinea }\end{array}$ & Philippines & UK \\
\hline & Netherlands & Spain & & Chile & France \\
\hline & Belgium & Australia & & Canada & USA \\
\hline & $\begin{array}{l}\text { New } \\
\text { Zealand }\end{array}$ & Japan & & New Zealand & Germany \\
\hline & Sweden & Italy & & Netherlands & Italy \\
\hline & Finland & Denmark & & Japan & Australia \\
\hline & UK & Canada & Samoa & New Zealand & Japan \\
\hline & Switzerland & France & & Australia & UK \\
\hline & USA & Norway & & Canada & Germany \\
\hline \multirow[t]{6}{*}{ Kiribati } & $\begin{array}{l}\text { New } \\
\text { Zealand }\end{array}$ & Germany & & USA & \\
\hline & Australia & Italy & Solomon & New Zealand & Germany \\
\hline & Japan & Switzerland & & Netherlands & Japan \\
\hline & UK & Canada & & Italy & Australia \\
\hline & France & USA & & UK & Canada \\
\hline & & & & France & USA \\
\hline \multirow[t]{4}{*}{ Marshall Islands } & Philippines & Germany & Tonga & New Zealand & France \\
\hline & USA & Fiji & & Canada & Italy \\
\hline & Japan & Australia & & Germany & USA \\
\hline & $\begin{array}{l}\text { New } \\
\text { Zealand }\end{array}$ & Canada & & $\begin{array}{l}\text { United } \\
\text { Kingdom }\end{array}$ & Japan \\
\hline \multirow[t]{3}{*}{ Micronesia } & Philippines & Japan & & Australia & \\
\hline & USA & $\begin{array}{l}\text { New } \\
\text { Zealand }\end{array}$ & Vanuatu & New Zealand & Japan \\
\hline & Canada & Australia & & Australia & \\
\hline \multirow[t]{3}{*}{ Palau } & Philippines & Germany & & & \\
\hline & USA & UK & & & \\
\hline & Japan & Switzerland & & & \\
\hline
\end{tabular}

\section{Results}

Table 3 shows the results of the estimations. Model 1 shows a single effect between tourism and migration stock, without including any of the variables. The result is significant, but the estimate may be subject to omitted variables bias. Model 2 shows the effect of other related 
variables, excluding migration. Most of the variables in this model are significant. In Model 3 , the migration variable is added to the other variables to explain tourism demand. Models 4-6 exclude the insignificant variables from Model 3 to compare the model fit. Model 6 indicates the best fit, based on the values of the AIC and $\log$ likelihood. Model 6 is thus the best model. In Model 3, the variance inflation factor (VIF) ranges from 1.24 to 3.23. In Model 6 , it ranges from 1.18 to 2.17 . The error terms are assumed to be normally distributed in this model. The Shapiro-Wilk test indicates accepting the null hypothesis that this data adopts the normal distribution and that the estimation method is appropriate.

Table 3: Estimation results.

\begin{tabular}{|c|c|c|c|c|c|c|c|c|c|c|c|c|}
\hline & Model1 & & Model2 & & Model3 & & Model4 & & Model5 & & Model6 & \\
\hline \multirow[t]{2}{*}{ (Intercept) } & 4.32 & $\star \star \star$ & 8.82 & $\star \star \star$ & 7.12 & $\star \star \star$ & 7.85 & $\star \star \star$ & 7.72 & $\star \star \star$ & 8.01 & $\star \star \star$ \\
\hline & $(0.42)$ & & $(2.31)$ & & $(2.00)$ & & $(1.97)$ & & $(1.86)$ & & $(1.86)$ & \\
\hline \multirow[t]{2}{*}{$\log$ (Migration) } & 0.54 & $\star \star \star$ & & & 0.29 & $\star \star \star$ & 0.35 & $\star \star \star$ & 0.30 & $\star \star \star$ & 0.35 & $\star \star \star$ \\
\hline & $(0.04)$ & & & & $(0.05)$ & & $(0.04)$ & & $(0.05)$ & & $(0.04)$ & \\
\hline \multirow[t]{2}{*}{$\log$ (GDPCAP) } & & & 0.78 & $\star \star \star$ & 0.64 & $\star \star \star$ & 0.58 & $\star \star \star$ & 0.62 & $\star \star \star$ & 0.58 & $\star \star \star$ \\
\hline & & & $(0.13)$ & & $(0.11)$ & & $(0.11)$ & & $(0.11)$ & & $(0.11)$ & \\
\hline \multirow[t]{2}{*}{$\log (\mathrm{POP})$} & & & 0.45 & $\star \star \star$ & 0.34 & $\star \star \star$ & 0.33 & $\star \star \star$ & 0.35 & $\star \star \star$ & 0.33 & $\star \star \star$ \\
\hline & & & $(0.07)$ & & $(0.07)$ & & $(0.07)$ & & $(0.06)$ & & $(0.06)$ & \\
\hline \multirow[t]{2}{*}{$\log (\mathrm{RP})$} & & & -0.14 & & -0.08 & & -0.02 & & & & & \\
\hline & & & $(0.11)$ & & $(0.10)$ & & $(0.09)$ & & & & & \\
\hline \multirow[t]{2}{*}{$\log ($ Distance $)$} & & & -2.10 & $\star \star \star$ & -1.62 & $\star \star \star$ & -1.61 & $\star \star \star$ & -1.68 & $\star \star \star$ & -1.63 & $\star \star \star$ \\
\hline & & & $(0.20)$ & & $(0.19)$ & & $(0.19)$ & & $(0.18)$ & & $(0.17)$ & \\
\hline \multirow[t]{2}{*}{ Language } & & & 1.40 & $\star \star \star$ & 0.39 & & & & 0.32 & & & \\
\hline & & & $(0.22)$ & & $(0.26)$ & & & & $(0.24)$ & & & \\
\hline \multirow[t]{2}{*}{ Colony } & & & 1.12 & $\star \star \star$ & 0.72 & $\star \star \star$ & 0.71 & $\star \star \star$ & 0.73 & $\star \star \star$ & 0.72 & $\star \star \star$ \\
\hline & & & $(0.27)$ & & $(0.24)$ & & $(0.25)$ & & $(0.24)$ & & $(0.24)$ & \\
\hline AIC & 294.55 & & 272.11 & & 251.13 & & 250.53 & & 246.99 & & 245.69 & \\
\hline $\mathrm{BIC}$ & 304.50 & & 294.51 & & 276.02 & & 272.92 & & 269.38 & & 265.60 & \\
\hline Log Likelihood & -143.27 & & -127.05 & & -115.56 & & -116.26 & & -114.49 & & -114.84 & \\
\hline Num.obs & 89 & & 89 & & 89 & & 89 & & 89 & & 89 & \\
\hline Num.Groups & 10 & & 10 & & 10 & & 10 & & 10 & & 10 & \\
\hline $\begin{array}{l}\text { Var: Destination } \\
\text { (Intercept) }\end{array}$ & 1.12 & & 2.04 & & 1.31 & & 1.19 & & 1.29 & & 1.19 & \\
\hline Var: Residual & 1.11 & & 0.67 & & 0.49 & & 0.51 & & 0.49 & & 0.50 & \\
\hline
\end{tabular}

Note: "Num.obs" is number of observations, and "Num.Groups" indicates the group of the destination states for random effect as equation 6 shows. Var intercept shows the variance of random intercept. () shows standard errors. Significance level $\star p<0.1, \star \star p<0.05, \star \star \star ~ p<0.01$

Based on these results, migration had an influence in tourism demand in the Pacific islands. When the migration stock in the countries of origin increases by $1 \%$, tourism demand changes by $0.35 \%$. Most other variables are also significant. In Model 6 , the income elasticity 
is 0.58 . An income elasticity of greater than 1 indicates a luxury good. For the Pacific islands, the income elasticity is less than 1. Moreover, relative price elasticity is insignificant. Previous work on tourism islands such as the Canary Islands, Mauritius, and Hawaii has shown the significant results for each of the economic variables (Garín-Mun, 2006; Khadaroo \& Seetanah, 2007; Fuleky et al., 2014). The differences may be due to the varying degrees of industrial agglomeration in the island tourism industries. Although the tourism industry is crucial for regional economies in this paper, fewer luxury-oriented industries are found in the sampled countries compared to in previous works. Relative price also ends being a insignificant variable for explaining tourism demand.

Other socioeconomic variables, such as market size of the countries of origin, are significant, though the elasticity has a low magnitude, meaning that when the market size changes by $1 \%$, tourism demand changes by $0.33 \%$ in Model 6 . The distance variable (measured as transportation cost) is significant. When distance changes by $1 \%$, demand elasticity changes by $-1.63 \%$. As previous studies have noted, remoteness is a regional characteristic. Furthermore, being a former colony shows an elastic relationship $(1.05 \%$ calculated by $(\exp (0.72)-1))$. In contrast, the common language variable is insignificant. English is the common language in these SIDS, but a common language has little effect on tourism demand.

\section{Discussion}

Migration affects tourism demand in the Pacific island region. As previous studies have shown, emigrants in foreign countries maintain relationships with local communities in their countries of origin. In terms of tourism demand, VFR, in which emigrant tourists visit friends and relatives in their countries of origin, is the form of tourism that is most closely related to migration.

The results indicate that island states in the Pacific region may possess this form of tourism demand, in common with developed countries such as Italy, New Zealand, and Australia that have been the focus of previous studies. In Italy, the elasticity of migration stock is shown to range from 0.05 to 0.23 (Etzo et al., 2014). Inbound tourism demand changes about $0.23 \%$ when migration stock changes $1 \%$ in New Zealand (Genç, 2013). The results in the present paper show a 0.35 elasticity of migration, meaning that the migration effect for these Pacific SIDS is slightly higher than those of previous studies. In their study of migration and Australia, Dwyer et al. (2014) find that the elasticity of migration stock ranges from 0.26 to 0.49 in 1991 and from 0.56 to 0.66 in 2006 , indicating a shift in the migration pattern in Australia).

Migrants from these island states influence international tourism demand in their countries of origin islands. This type of tourism demand is likely to be relatively stable compared with other types of travel, such as leisure tourism. The results of this research thus suggest that it is important for tourism policies to take into account migration linkages and diversified tourism demand such as VFR.

That said, most of the socioeconomic variables in our study are significant. The distance variable (represented by transportation costs) and the colonial history variable show elastic results. Remoteness is one of the regional characteristics of small islands. From an international trade perspective, this situation is disadvantageous to island economies. Based on the estimation result, this geographical characteristic may also influence tourism demand in SIDS in the Pacific region. Furthermore, relationships with sovereign states are significant for tourism demand, even though the selected Pacific SIDS only include current independent states. Socioeconomic factors should also be considered in tourism demand, especially the transportation situation and colonial relationships. 


\section{Conclusions}

This study discusses linkages between the migration effect and tourism demand in Pacific region SIDS. On the basis of the results, migrants from ten Pacific Islands affect tourism demand. This might be due to migrants' friendship and kinship networks and their influence on VFR tourism, given that some migrants maintain strong connections to local communities within their countries of origin and ancestral homelands, consistent with the MIRAB categorization.

More research is needed into the tourism and migration nexus. Although this paper demonstrates the interaction of migration stock and tourism demand in Pacific island countries, the mechanisms of both relationships are unidentified. For example, it is crucial to understand tourist motivations. Previous studies focusing on diaspora tourism or roots tourism seek to assess the feelings of descendants when they return to their ancestral homelands as well as their perceptions of relationships between the ancestral homelands and their current homes (Lam, 2019; Huang et al., 2013; Iorio et al., 2013). This perspective is also likely to become significant for island regions as the future research topic.

\section{References}

Armstrong, H., \& Read, R. (2006). Geographical 'handicaps' and small states: some implications for the Pacific from a global perspective. Asia Pacific Viewpoint, 47(1), 7992. https://doi.org/10.1111/j.1467-8373.2006.00294.x

Armstrong, H.W., \& Read, R. (2003). Small states, islands and small states that are also islands. Studies in Regional Science, 33(1), 237-260. https://doi.org/10.2457/srs.33.237

Armstrong, H.W., \& Read, R. (2002). The phantom of liberty?: Economic growth and the vulnerability of small states. Journal of International Development, 14(4), 435-458. https://doi.org/10.1002/jid.886

Balli, F., Balli, H.O., \& Louis, R.J. (2016). The impacts of immigrants and institutions on bilateral tourism flows. Tourism Management, 52, 221-229.

https://doi.org/10.1016/j.tourman.2015.06.021

Bertram, G., \& Watters, R.F. (1985). The MIRAB Economy in South Pacific microstates. Asia Pacific Viewpoint, 26(3), 497-519.

Browne, C., \& Mineshima, A. (2007). Remittances in the Pacific region. IMF Working Papers, 07/35, 1-14.

Briguglio, L.P. (1998). Small country size and returns to scale in manufacturing. World Development, 26(3), 507-515. https://doi.org/10.1016/S0305-750X(97)10059-6

Briguglio, L. (1995). Small island developing states and their economic vulnerabilities. World Development, 23(9), 1615-1632. https://doi.org/10.1016/0305750X(95)00065-K

Christensen, A.E., \& Mertz, O. (2010). Researching Pacific island livelihoods: mobility, natural resource management and nissology. Asia Pacific Viewpoint, 51(3), 278-287. https://doi.org/10.1111/j.1467-8373.2010.01431.x

Dwyer, L., Forsyth, P., \& Dwyer, W. (2010). Tourism economics and policy. Bristol: Channel View.

Dwyer, L., Seetaram, N., Forsyth, P., \& King, B. (2014). Is the migration-tourism relationship only about VFR? Annals of Tourism Research, 46, 130-143. https://doi.org/10.1016/j.annals.2014.03.009

Dogru, T., Sirakaya-Turk, E., \& Crouch, G.I. (2017). Remodeling international tourism demand: old theory and new evidence. Tourism Management, 60, 47-55. https://doi.org/10.1016/j.tourman.2016.11.010 
Egger, P.H., Von Ehrlich, M., \& Nelson, D.R. (2012). Migration and trade. The World economy, 35(2), 216-241. https://doi.org/10.1111/j.1467-9701.2011.01429.x

Garín-Mun, T. (2006). Inbound international tourism to Canary Islands: a dynamic panel data model. Tourism Management, 27(2), 281-291. https://doi.org/10.1016/j.tourman.2004.10.002

Eilat, Y., Einav, L. (2004). Determinants of international tourism: a three-dimensional panel data analysis. Applied Economics, 36(12). 1315-1327. https://doi.org/10.1080/000368404000180897

Etzo, I., Massidda, C., and Piras, R. (2014). Migration and outbound tourism: evidence from Italy. Annals of Tourism Research, 48, 235-249. https://doi.org/10.1016/j.annals.2014.07.002

Fourie, J., \& Santana-Gallego, M. (2011). The impact of mega-sport events on tourist arrivals. Tourism Management, 32(6), 1364-1370. https://doi.org/10.1016/j.tourman.2011.01.011

Fourie, J., \& Santana-Gallego, M. (2013). Ethnic reunion and cultural affinity. Tourism Management, 36, 411-420. https://doi.org/10.1016/j.tourman.2012.10.002

Fuleky, P., Zhao, Q., \& Bonham, C. S. (2014). Estimating demand elasticities in nonstationary panels: the case of Hawaii tourism. Annals of Tourism Research, 44, 131-142. https://doi.org/10.1016/j.annals.2013.09.006

Guan, J., \& McElroy, J.L. (2012). The determinants of migration in small islands. Shima, $7(1), 80-95$.

Garín-Mun, T. (2006). Inbound international tourism to Canary Islands: a dynamic panel data model. Tourism Management, 27(2), 281-291. https://doi.org/10.1016/j.tourman.2004.10.002

Genç, M. (2013). Migration and tourism flows to New Zealand. In Á. Matias, P. Nijkamp, \& M. Sarmento (Eds) Quantitative methods in tourism economics (pp. 113-126). Heidelberg: Physica. https://doi.org/10.1007/978-3-7908-2879-5 7

Huang, W.J., Haller, W.J., \& Ramshaw, G.P. (2013). Diaspora tourism and homeland attachment: an exploratory analysis. Tourism Analysis, 18(3), 285-296. https://doi.org/10.3727/108354213X13673398610691

Iorio, M., \& Corsale, A. (2013). Diaspora and tourism: Transylvanian Saxons visiting the homeland. Tourism Geographies, 15(2), 198-232. https://doi.org/10.1080/14616688.2012.647327

Keum, K. (2010). Tourism flows and trade theory: a panel data analysis with the gravity model. The Annals of Regional Science, 44(3), 541-557. https://doi.org/10.1007/s00168-008-0275-2

Khadaroo, J., \& Seetanah, B. (2007). Transport infrastructure and tourism development. Annals of Tourism Research, 34(4), 1021-1032. https://doi.org/10.1016/j.annals.2007.05.010

Lam, K. (2019). Island-raised but foreign-made: lived experiences, transnational relationships, and expressions of womanhood among Cape Verdean migrant women in Greater Lisbon. Island Studies Journal, 14(1). https://doi.org/10.24043/isj.71

Liu, A., Song, H., \& Blake, A. (2018). Modelling productivity shocks and economic growth using the Bayesian dynamic stochastic general equilibrium approach. International Journal of Contemporary Hospitality Management, 30(11), 3229-3249. https://doi.org/10.1108/IJCHM-10-2017-0686

Lim, C. (1997). Review of international tourism demand models. Annals of Tourism Research, 24(4), 835-849. https://doi.org/10.1016/S0160-7383(97)00049-2 
Seetaram, N. (2012). Immigration and international inbound tourism: empirical evidence from Australia. Tourism Management, 33(6), 1535-1543. https://doi.org/10.1016/j.tourman.2012.02.010

Mayer, T., \& Zignago, S. (2011). Notes on CEPII's distances measures: the GeoDist Database. CEPII Working Paper, 2011-25. https://doi.org/10.2139/ssrn.1994531

Narayan, P.K., Narayan, S., Prasad, A., \& Prasad, B.C. (2010). Tourism and economic growth: a panel data analysis for Pacific Island countries. Tourism Economics, 16(1), 169-183. https://doi.org/10.5367/000000010790872006

Pratt, S. (2015). The economic impact of tourism in SIDS. Annals of Tourism Research, 52, 148-160. https://doi.org/10.1016/j.annals.2015.03.005

Seetanah, B. (2011). Assessing the dynamic economic impact of tourism for island economies. Annals of Tourism Research, 38(1), 291-308. https://doi.org/10.1016/j.annals.2010.08.009

Song, H., \& Li, G. (2008). Tourism demand modelling and forecasting: a review of recent research. Tourism Management, 29(2), 203-220. https://doi.org/10.1016/j.tourman.2007.07.016

Song, H., Dwyer, L., Li, G., \& Cao, Z. (2012). Tourism economics research: a review and assessment. Annals of Tourism Research, 39(3), 1653-1682. https://doi.org/10.1016/j.annals.2012.05.023

Vietze, C. (2012). Cultural effects on inbound tourism into the USA: a gravity approach. Tourism Economics, 18(1), 121-138. https://doi.org/10.5367/te.2012.0100

Williams, A.M., \& Hall, C.M. (2000). Tourism and migration: new relationships between production and consumption. Tourism Geographies, 2(1), 5-27. https://doi.org/10.1080/146166800363420

Witt, S.F., \& Witt, C.A. (1995). Forecasting tourism demand: a review of empirical research. International Journal of Forecasting, 11(3), 447-475. https://doi.org/10.1016/0169-2070(95)00591-7

World Bank (2017). World development indicators. World Bank. http://data.worldbank.org/

World Bank (2013). The migration and remittances factbook. World Bank. http://www.worldbank.org/en/topic/migrationremittancesdiasporaissues/brief/migra $\underline{\text { tion-remittances-data }}$

World Tourism Organization. (2015). Yearbook of tourism statistics [Data File]. Madrid: UNWTO.

UNO-OHRLLS (2016). About the Small Island Developing States. UNO-OHRLLS. http://unohrlls.org/

Zhang, J., \& Jensen, C. (2007). Comparative advantage: explaining tourism flows. Annals of Tourism Research, 34(1), 223-243. https://doi.org/10.1016/j.annals.2006.08.004 
Kantaro Takahashi 